\title{
Reducing the Amount of Nitrate and Nitrite in Anna Apple Fruits by Using Inorganic N Along with EM, Yeast and Humic Acid
}

\author{
Osama Aly Mohamed El-Sehrawy 1
}

\begin{abstract}
During 2009 and 2010 seasons, three bio-stimulants namely EM (Effective Microorganisms), yeast and humic acid were used as a trial for replacing inorganic $\mathbf{N}$ partially in Anna apple orchard.

Combined application of inorganic $\mathrm{N}$ beside any biostimulants was favorable than using inorganic $\mathrm{N}$ alone in improving growth, nutritional status of the trees as well as yield and fruit quality. The best biostimulant was EM. Humic acid ranked the second position in this concern.

For reducing pollution due to nitrate and nitrite in the fruits and for improving production of Anna apple, it is advised to use $N$ as inorganic $N$ at $60 \%$ of the suitable $N$ dose along with application of EM or humic acid each at $30 \mathrm{ml} /$ tree/year.
\end{abstract}

\section{INTRODUCTION}

A principal goal of nature farming is to produce abundant and healthy crops not only without the use of both chemical fertilizers and pesticides but also without causing adverse effects on the natural environment. Means of achieving this goal are through the use of effective microorganisms (EM), humic substances and yeast.

EM is beneficial in suppressing of plant pathogens and diseases, conservation energy in plants, solublization of soil minerals, soil microbial ecological balance, photosynthetic efficiency and biological $\mathrm{N}$ fixation (Higa and Widiana, 1991 and El- Haddad et al., 1993).

Biostimulants are known as the organic materials which promote plant growth and help plants to withstand hashed environments when applied in small quantities (Chen et al., 1994). Using of humic acid and related products to increase nutrient uptake, tolerance to drought and temperature extremes, activity of beneficial soil microorganisms, and availability of soil nutrients particularly in alkaline soils and low organic matter (Senn and Kingman, 1973 and Russo and Berlyn, 1990). Also, humic materials may increase root growth in a similar manner to auxins (Senn and Kingman, 1973; and Tatini, et al., 1991). Finally, using organic fertilizers such as humic substances covers all forms of organic soil amendments and was responsible for enhancing biological cycles such as improving soil fertility and hormones (Dahama, 1999).

Recently, the yeast attention has been focused on the possibility of using natural and safety substances in order to improve plant growth, yield and quality of many crops. Bio-fertilizers have been extensively used as an eco-friendly approach to minimize the use of chemical fertilizers, improve soil fertility status and for the enhancement of crop production by their biological activity in the rhizosphere (Kannaiyan, 2002).

Yeast (Saccharomyces cervisiae, $L$ ) is considered as one of the promising bio-fertilizers for many crops. The positive effect of yeast's application could be due to its effect in activating photosynthesis process through enhancing the release of $\mathrm{CO}_{2}$, as well as its higher own content not only from natural growth regulators namely IAA, $\mathrm{GA}_{3}$ and cytokinins, but also both of amino acids and B-vitamins. Also, yeast is responsible for encouraging the uptake of different nutrients (AbouZaid, 1984 and Barnett et al., 1990).

Using organic, bio-fertilizers especially humic substances and effective microorganisms(EM) were very effective in stimulating growth and fruiting of different deciduous fruit crops (Petrovic et al., 1982; Patti et al., 1988; Davis and Ghabbour, 1998; Mansour, 1998; Mansour et al., 1998; Myint,1999;Fathi et al., 2002; Eissa- Fawzia ,2003a,b; Kabeel et al., 2005; Shaddad et al., 2005; Barakat et al., 2007; Kabeel et al., 2007; El- Sehrawy, 2008; Kabeel et al., 2008; ElNaggar, 2009 and Gad El- Kareem, 2009).

The essential role of yeast on growth and fruiting of various deciduous fruit crops was mentioned (AboTaleb, Safia et al., 1999; El- Sayed, 2001; NumairSafaa, 2001; Bakry and Wanas, 2003; Abd El- Hameed, 2005; Abd El- Wahab et al., 2005; Gaser- Aisha et al., 2006; Hegab et al., 2010 and Ahmed, 2011).

The merit of this study was examining the possibility of reducing the amount of nitrate and nitrite in Anna apple fruits by using inorganic $\mathrm{N}$ along with EM, yeast and humic acid. Selecting the best biostimulant applied with inorganic $\mathrm{N}$ is considered another target.

\footnotetext{
${ }^{1}$ Environmental Studies \& Research Institute (ESRI),Sadat City University (SCU), Egypt.

oaelsehrawy@gmail.com

Received June 3, 2015, Accepted June 29, 2015
} 


\section{MATERIALS AND METHODS}

This study was carried out during 2009 and 2010 seasons on 39 uniforms in vigor-13 year's old- Anna apple trees grafted onto MM 106 rootstock and grown in a private apple orchard located at west Samalout, Minia governorate, Egypt. The soil analysis -according to Chapman and Pratt, 1961 -was sandy with salinity reached $2500 \mathrm{ppm}$ (Table 1). The trees were planted at a spacing of $3.5 \mathrm{~m}$ between rows and $3.5 \mathrm{~m}$ within row making a total of 327 trees/fed. The orchard was under a good management program which was reflected in the good tree's appearance. Dorset Golden and Ein Shamir apple trees were additionally distributed beside Anna apple trees at proportion of four rows from Anna apple trees to one row of the two previous pollinizers to secure cross pollination with the assistance of two hives of honey bees per fed. Surface irrigation system was followed.

The present study included the following thirteen treatments from inorganic $\mathrm{N}$ and the three biostimulants (EM, yeast or humic acid):-

1- Application of the suitable N (400 g N/tree/year) completely via inorganic form (1941.7 $\mathrm{g}$ ammonium sulphate, $20.6 \% \mathrm{~N}$ ), common treatment added in this area as a control.

2- Application of $\mathrm{N}$ via inorganic $\mathrm{N}$ form at $80 \%$ (1553.4 g ammonium sulphate/tree/year) alone.

3- Application of $\mathrm{N}$ via inorganic $\mathrm{N}$ form at $80 \%$ (as treat.2) plus EM at $30 \mathrm{ml} /$ tree/year.

4- Application of $\mathrm{N}$ via inorganic $\mathrm{N}$ form at $80 \%$ (as treat.2) plus yeast at $75 \mathrm{~g} /$ tree/year.

5- Application of $\mathrm{N}$ via inorganic $\mathrm{N}$ form at $80 \%$ (as treat.2) plus humic acid at $30 \mathrm{ml} /$ tree/year.

6- Application of $\mathrm{N}$ via inorganic $\mathrm{N}$ form at $60 \%$ ( $1165.0 \mathrm{~g}$ ammonium sulphate/tree/year) alone.

7- Application of $\mathrm{N}$ via inorganic $\mathrm{N}$ form at $60 \%$ (as treat.6) plus EM at $30 \mathrm{ml} /$ tree/year.

8- Application of $\mathrm{N}$ via inorganic $\mathrm{N}$ form at $60 \%$ (as treat.6) plus yeast at $75 \mathrm{~g} /$ tree/year.

9- Application of $\mathrm{N}$ via inorganic $\mathrm{N}$ form at $60 \%$ (as treat.6) plus humic acid at $30 \mathrm{ml} /$ tree/year.

10- Application of $\mathrm{N}$ via inorganic $\mathrm{N}$ form at $40 \%$ ( $776.7 \mathrm{~g}$ ammonium sulphate/tree/year) alone.

11- Application of $\mathrm{N}$ via inorganic $\mathrm{N}$ form at $40 \%$ (as treat.10) plus EM at $30 \mathrm{ml} /$ tree/year).

12- Application of $\mathrm{N}$ via inorganic $\mathrm{N}$ form at $40 \%$ (as treat.10) plus yeast at $75 \mathrm{~g} /$ tree/year.

13- Application of $\mathrm{N}$ via inorganic $\mathrm{N}$ form at $40 \%$ (as treat.10) plus humic acid at $30 \mathrm{ml} /$ tree/year.
Each treatment was replicated three times, one tree per each. Nitrogen at the recommended rate namely 400 $\mathrm{g} \mathrm{N} /$ tree/year was added via ammonium sulphate source $(20.6 \% \mathrm{~N})$. The three bio- stimulants namely: 1-EM (Effective Microorganisms) at 30ml/tree/ year, 2-Yeast at $75 \mathrm{~g} /$ tree/year and 3- Humic acid at $30 \mathrm{ml} /$ tree/year; were applied via soil and divided into three equal batches (at growth start, just before first bloom and at fruit setting stage). All horticultural practices were applied as usual for all used treatments. A Complete Randomized Block Design (CRBD) was followed.

The pure yeast powder was activated by using sources of carbon and nitrogen with ratio of $6: 1$. This ratio is suitable to get the highest vegetative production of yeast. Each $\mathrm{ml}$ of activated yeast contained about 12000 yeast cells (Barnett et al., 1990). Such technique allowed yeast cells to grow multiplied efficiently during conductive aerobic and nutritional conditions. To produce de novo beneficial bio-constituents i.e. phytohormones, carbohydrates, proteins, amino acids, fatty acids, vitamins, enzymes, minerals.... etc., hence allowed such constituents to release out of yeast tissues in readily form. Such technique for yeast preparations based on: 1- Nutritional media of glucose and casein as favorable sources of $\mathrm{C}, \mathrm{N}$ and other essential elements (P, K, Mg, Fe, Mn, $\mathrm{Cu}, \mathrm{B}$ and $\mathrm{Mo}, \mathrm{Na}$ ), 2- In suitable balance (Barnett et al., 1990), 3- Air pumping and adjusting incubation temperature. The media then subjected to two cycles of freezing and thawing for disruption of yeast tissues and releasing their bioconstituents directly before using.

Leaf area $\left(\mathrm{cm}^{2}\right)$ was measured according to Ahmed and Morsy (1999) equation. For measuring percentages of N, P and $\mathrm{K}$ in the leaves; samples of twenty leaves per each treated apple tree were taken at random from the middle parts of current shoots at two weeks after fruit setting (according to Summer, 1985).

Yield of each treated apple tree was recorded at harvesting time (last week of June) as weight in $\mathrm{kg}$. Samples consisting of ten fruits were randomly taken from each tree for determinations of fruit weight (g.), total soluble solids \% (T.S.S), total and reducing sugars $\%$ (according to Lane and Eynon, volumetric method, 1965, A.O.A.C, 1995), total acidity \%(expressed as g malic acid/100 g pulp), and finally both of nitrate and nitrite in the pulp (ppm) (according to the procedure outlined in A.O.A.C, 1995).

All the obtained data were tabulated and statistically analyzed according to Mead et al. (1993). The differences between various treatment means were tested by using new L.S.D parameter. 
Table 1. Analysis of the tested soil

\begin{tabular}{lc}
\hline \multicolumn{1}{c}{ Characters } & Values \\
\hline Sand $\%$ & $76.0 \%$ \\
\hline Silt $\%$ & $10.0 \%$ \\
\hline Clay $\%$ & $14.0 \%$ \\
\hline Texture & Sandy \\
\hline E.C. $\left(1: 2.5\right.$ extract) $\left(\mathrm{mmhos}^{\prime} / \mathrm{cm}^{3} / 25^{\circ} \mathrm{C}\right)$ & 0.97 \\
\hline pH $(1: 2.5$ extract $)$ & 7.52 \\
\hline O.M. $\%$ & $0.50 \%$ \\
\hline CaCO $\%$ & $3.20 \%$ \\
\hline Total N $\%$ & $0.03 \%$ \\
\hline Available P (Olsen method, ppm) & 2.2 \\
\hline Available K (ammonium acetate, $\mathrm{ppm})$ & 69.5 \\
\hline
\end{tabular}

Table 2. Chemical analysis of the tested yeast

\begin{tabular}{cccccccc}
\hline $\begin{array}{c}\mathbf{N} \\
\%\end{array}$ & Fats \% & Ash \% & $\begin{array}{c}\text { Vitamin } \mathbf{B}_{\mathbf{1}} \\
(\text { Thiamine) } \\
(\mathbf{1 0 0} \mathbf{g})\end{array}$ & $\begin{array}{c}\text { Vitamin } \mathbf{B}_{2} \\
(\text { Riboflavin) } \\
(\mathbf{1 0 0} \mathbf{g})\end{array}$ & $\begin{array}{c}\text { Vitamin } \mathbf{B}_{3} \\
(\text { Niacin) } \\
(\mathbf{1 0 0} \mathbf{g})\end{array}$ & $\begin{array}{c}\text { Vitamin } \mathbf{B}_{\mathbf{6}} \\
\text { (Pyridoxine) } \\
(\mathbf{1 0 0} \mathbf{g})\end{array}$ & $\begin{array}{c}\text { Vitamin } \mathbf{B}_{\mathbf{1 2}} \\
\text { (Cobalamin) } \\
(\mathbf{1 0 0} \mathbf{g})\end{array}$ \\
\hline 7.3 & 3.5 & 6.7 & $2.33 \mathrm{mg}$ & $5.41 \mathrm{mg}$ & $36.7 \mathrm{mg}$ & $4.41 \mathrm{mg}$ & $0.02 \mathrm{mg}$ \\
\hline
\end{tabular}

\section{RESULTS AND DISCUSSION}

\section{1- Leaf area:}

It is clear from the obtained data in Table (3) that varying inorganic $\mathrm{N}$, yeast, humic acid and Effective Microorganisms (EM) treatments had significant effect on the leaf area of the tested Anna apple trees. Increasing percentages of inorganic $\mathrm{N}$ with $\mathrm{EM}$ at 30 $\mathrm{ml}$ applied either alone/tree or in combined with humic acid at $30 \mathrm{ml}$ caused a gradual and significant promotion on the leaf area. Application of yeast, humic acid and EM, in ascending order in combined with Inorganic $\mathrm{N}$ at 40 to $80 \%$ out the suitable $\mathrm{N}$ was significantly very effective in stimulating the leaf area. The best organic and biostimulants in this respect was "EM" followed by "humic acid", and "yeast" came in the last position in this respect. Increasing percentages of inorganic $\mathrm{N}$ from 60 to $80 \%$ out of the suitable $\mathrm{N}$ especially without the application of any biostimulants had a slight and significant stimulation on the leaf area. An outstanding and significant promotion on the leaf area was observed with using inorganic $\mathrm{N}$ source at 40 to $80 \%$ beside the suitable application of any organic and biostimulants rather than application of organic $\mathrm{N}$ alone. A significant reduction on the leaf area was observed with reducing inorganic $\mathrm{N}$ from 60 to $40 \%$ out of the suitable $\mathrm{N}$ even with the application of any organic and biostimulants. The maximum leaf area was presented in the Anna apple trees that received the suitable $\mathrm{N}$ via $80 \%$ inorganic $\mathrm{N}$ source plus using $\mathrm{EM}$ at $30 \mathrm{ml} /$ tree/year. Fertilizing the trees with $\mathrm{N}$ through $40 \%$ inorganic without using any organic and biostimulants gave the minimum values. These results were true during 2009 and 2010 seasons.
The positive action of yeast, humic acid and EM in enhancing soil fertility, secreting natural hormones and amending the plants with their requirements from nutrients, amino acids, organic acids and antioxidants (Dahama, 1999 and Kannaiyan, 2002) could explain the present results.

These results are in agreement with those obtained by Barky and Wanas (2003) on yeast and humic acid which significantly increased fruit growth of apricot trees, Alva and Obreza (1998) on humic materials which significantly increased orange and grapefruit trees growth, El-Sehrawy (2008) on EM which increased growth of apple trees, Kabeel et al. (2008) on humate fertilizers which increased growth of pear trees, Fathi, et al. (2002) on bio- stimulants applications which enhanced most of growth parameters of peach and apple trees.

\section{2- Percentages of $N, P$ and $K$ in the leaves:}

Percentages of N, P and $\mathrm{K}$ in the leaves of Anna apple trees were significantly different among all inorganic $\mathrm{N}$, yeast, EM and humic acid treatments. Percentage of $\mathrm{N}$ was gradually increased, while both $\mathrm{P}$ and $\mathrm{K}$ were gradually reduced with increasing percentages of inorganic $\mathrm{N}$ as well as application of EM, yeast or humic acid. Application of EM, yeast, humic acid beside inorganic $\mathrm{N}$ fertilization significantly accompanied with enhancing the three nutrients comparing with using inorganic $\mathrm{N}$ fertilization alone. The beneficial effect of these organic and biostimulants on enhancing these nutrients was arranged as follows in ascending order: yeast, humic acid and EM. Supplying the trees with $\mathrm{N}$ via inorganic source alone (100\% inorganic source) without using any organic and 
biostimulants resulted in the maximum percentage of $\mathrm{N}$ in the leaves. The maximum values of both $\mathrm{P}$ and $\mathrm{K}$ were observed on the trees that received the suitable $\mathrm{N}$ through $40 \%$ inorganic $\mathrm{N}$ plus application of EM. Fertilizing the trees with $\mathrm{N}$ as $40 \%$ inorganic $\mathrm{N}$ source gave the minimum values of $\mathrm{N}$. Treating the trees with completely Inorganic $\mathrm{N}$ at $100 \%$ alone(Control) gave the minimum values of $\mathrm{P}$ and $\mathrm{K}$ nutrients. These results were true during both seasons (Table 2).

The positive action of these organic and biostimulants on enhancing nutrients in the leaves was mainly attributed to their effect in lowering soil $\mathrm{pH}$, enhancing soil fertility and organic matter which were reflected on enhancing the availability of various nutrients (Dahama, 1999 and Kannaiyan, 2002). The reduction of $\mathrm{P}$ and $\mathrm{K}$ in the present results was attributed to the dilution effect as well as to the antagonism occurred between $\mathrm{N}$ from one side and both $\mathrm{P}$ and $\mathrm{K}$ in the other side.

However, Chunhua et al. (1998) showed that the promoting effect of these products is due to their increase of cation exchange capacity which affects the retention and availability of nutrients, or due to a hormonal effect, or a combination of both.

\section{3- Yield/ tree}

As shown from data in Table (3), yield/tree was significantly altered according to the present inorganic $\mathrm{N}$, EM, yeast and humic acid treatments. The promotion on the yield was associated significantly with increasing inorganic $\mathrm{N}$ percentages and at the same time application of yeast, humic acid and EM. A significant decline on the yield was observed when the suitable $\mathrm{N}$ was applied via inorganic $\mathrm{N}$ form at percentages lower than $60 \%(40 \%)$ even with the application of the three biostimulants (yeast, humic acid or EM). Reducing inorganic N from 80 to $60 \%$ with the application of any of the three biostimulants had a slight and insignificant reduction on the yield. In ascending order, the superiority of these biostimulants on improving the yield can be arranged as follows: yeast, humic acid and EM. In most cases application of the suitable $\mathrm{N}$ via inorganic $\mathrm{N}$ plus any of these biostimulants was significantly preferable in improving the yield comparing with non- application of these biostimulants and application of $\mathrm{N}$ via inorganic $\mathrm{N}$ alone. Supplying Anna trees with N via $60 \%$ inorganic $\mathrm{N}$ plus $\mathrm{EM}$ at $30 \mathrm{ml} /$ tree/ year gave an economical yield. This lowest yields ( 32.0 and $33.2 \mathrm{~kg}$ during both seasons, respectively) were recorded on the trees received $\mathrm{N}$ via inorganic $\mathrm{N}$ at $40 \%$ alone (without any biostimulant). The promising treatment (60\% inorganic
$\mathrm{N}$ plus EM at $30 \mathrm{ml} /$ tree/year) produced yield reached 47.9 and $49.0 \mathrm{~kg}$ during both seasons, respectively.

The beneficial effect of the three biostimulants (yeast, humic acid and EM) on the yield might be attributed to their positive action on growth and nutritional status of the trees.

These results are in agreement with those obtained by Bakry and Wanas (2003) on yeast which increased fruit production of apricot trees, Alva and Obreza (1998) on yeast and humic acid which significantly increased fruit production of orange and grapefruit trees, Li, et al.(1999) on humate fertilizers which enhanced apple fruit weight and yield, Kabeel et al.(2008) on humate fertilizers which increased fruit production of pear trees, El-Sehrawy (2008) on EM which increased fruit production of apple trees, Fathi et al.(2002) on bio- stimulants which increased fruit quality and grower income yield of both apple and peach trees, and Faissal et al. (2014) on humic acid and EM which increased yields of Zaghloul Date Palm.

\section{4- Physical and chemical characteristics of the fruits:-}

It is clear from the data in Tables $(3 \& 4)$ that both physical and chemical characteristic of Anna apple fruits were significantly varied according to the present treatments. Combined application of the suitable $\mathrm{N}$ via inorganic $\mathrm{N}$ with any of the three biostimulants (yeast, humic acid or EM) was favorable from statistical point of view in improving quality of the fruits in terms of increasing fruit weight ,T.S.S \% ,total reducing and non- reducing sugars $\%$ and reducing total acidity $\%$ as well as nitrate and nitrite in the pulp rather than application of $\mathrm{N}$ via inorganic $\mathrm{N}$ source alone (without using any biostimulants).The stimulation on fruit quality was significantly depended on increasing inorganic $\mathrm{N}$ percentages as well as application of any of the three biostimulants. A negative effect of both physical and chemical characteristics was attributed to reducing inorganic $\mathrm{N}$ to be $40 \%$ even with the application of any of the three used biostimulants. A slight and insignificant adverse effect on quality of the fruits was observed due to reducing percentages of inorganic $\mathrm{N}$ from 80 to $60 \%$ beside the application of any of the three used biostimulants. Supplying the trees with $\mathrm{N}$ via $60 \%$ inorganic $\mathrm{N}$ enriched with $\mathrm{EM}$ at 30 $\mathrm{ml} /$ tree/year gave the best results with regard to quality parameters. Application of $\mathrm{N}$ through $40 \%$ inorganic without using any biostimulant gave unfavorable effects on fruit quality. These results were true during both experimental seasons. 
The outstanding effect of these biostimulants on quality of the fruits was attributed to their positive action on enhancing the cell division and building of organic foods especially total carbohydrates. The great 
effects of these biostimulants on decomposition and transformation of inorganic $\mathrm{N}$ to undamaged state surely reflected in reducing nitrate and nitrite in the pulp of Anna apple fruits.

These results are in agreement with those obtained by Abd El- Hameed (2005) on yeast which improved yield and fruit quality of grapevines, Barky and Wanas(2003)on yeast which enhanced apricot fruit trees, Fathi et al. (2002) on biostimulants which improved yield and fruit quality of both peach and apple, Kabeel et al. (2008) on humic acid which improved fruiting and nutritional status of pear trees, Khattab et al.(2012) on humate fertilizers which increased yield and fruit quality of pomegranate trees, El-Sehrawy (2008) on EM which improved yield and significantly increased fruit quality of apple trees, Ahmed-Samah (2011) on yeast and EM, Faissal et al. (2014) on humic acid and EM which significantly improved fruit quality of Zaghloul Date Palm, and Mansour et al. (2013) on EM and humic acid which not only improved both yield and fruit quality of peach but also reduced pollution.

As a conclusion, it is preferable for using EM at 30 $\mathrm{ml} /$ tree/ year beside inorganic $\mathrm{N}$ at $60 \%$ of the suitable $\mathrm{N}$ (400 g N/tree/ year) for improving yield quantitatively and qualitatively as well as controlling pollution with nitrate and nitrite in Anna apple orchard.

\section{REFERENCES}

Abd El- Hameed, H. M. (2005). Response of Red Roomy grapevines to Algae extract, yeast and mono potassium phosphate fertilizer. Minia J. of Agric. Res. \& Dev. Vol. (25) No. 5 pp. 883 - 904.

Abd El- Wahab, M. A.; Gaser- Aisha, S. A. and Massoud, O. N. (2005). Role of acrbuscular mycorhiza and yeast in improving quality of Black Monaka grapes. J. of Agric. Sci. Mansoura Univ., 33 (1): 393 - 417.

Abo-Taleb, Safia, A.; Osman, H. L. and Yossef, F. N. (1999). Effect of soil application of active dry yeast (Saccharomyces cerevisiae) on growth and fruiting in pomegranate trees. Minufiya, J. of Agric. Res.24 (1), 289304.

Abou-Zaid, M. (1984). Biochemical studies on fodder yeast. Ph.D. Thesis, Fac. of Agric. Cairo Univ., Egypt.

Ahmed, F.F. and M.H. Morsy. (1999). A new method for measuring leaf area in different fruit species. Minia J. Agric. Res. \& Develop.19: 97- 105.

Ahmed, O. M. M. (2011). Effect of some yeast and slow release nitrogen fertilizer treatments on Red Roomy grapevine (Vitis vinifera L.).M.Sc. Thesis. Fac. of Agric. Minia Univ., Egypt.

Ahmed- Samah, O. O. (2011). Effect of yeast and effective microorganisms (EM) application on yield and fruit characteristics of Bartamuda date palm under Aswan climatic conditions. M. Sc. Thesis, Fac. of Agric. Assiut Univ., Egypt.

Alva, A. K. and T. A. Obreza. (1998). By-product Ironhumate increases tree growthand fruit production of orange and grapefruit. Hort. Sci. 33 (1): $71-74$.

Association of Official Agricultural Chemists.(1995).Official Methods of Analysis (A.O.A.C), $15^{\text {th }}$ Ed. Benjamin Franklin Station, Washington, D.C. U.S.A. pp. $490-550$.

Bakry, Kh. A. E. and Wanas, A. L. (2003). Response of Amar apricot trees to spray with yeast extract and Kinetin. Egypt. J. of Appl. Sci., 18 (6): 319 - 336.

Barakat, M. R.; Yehia, T. A.; Saleh, W. D. and Sayed, B. M. (2007). Effect of organic and biofertilization on growth and productivity of peach trees cv. Floridaprince, IFlowering and fruiting characteristics. Egypt. J. of Appl. Sci., 22 (6A): $270-282$.

Barnett, J. A.; Payne, R. W. and Yarrow, D. (1990). Yeast Characteristics and Identification. Cambridge Univ., Press London.

Chapman, H. D. and Pratt, P. E. (1961).Methods of Analysis for Soil, Plant and Water. California Univ. Division of Agric. Sci., USA.

Chen, Y.; H. Magen and J. Riov. (1994). Humic substances originating from rapidlydecomposing organic matter. Proc. Int. Meet. $6^{\text {th }}$ Sep. 1992: $427-443$, (Chem. Abst. 121:229).

Chunhua, L.; R. J. Cooper and D. C. Bowman. (1998).Humic acid application affectsphotosynthesis, root development and nutrient content of creeping bentagrass. Hort. Sci. 33 (6): 1023 - 1025.

Dahama, A. K. (1999). Organic Farming for Sustainable Agriculture. Agro, Botanic, Daryagun, New Delhi, India, p. 258.

Davis, G. and Ghabbour, E. A. (1998). Humic substances, structure properties and uses. Royal Soc. of Chemistry, Cambridge, pp. 10 - 15.

Eissa, Fawzia M.(2003a). Use of some biostimulants in activation of soil microflora for yield and fruit quality improvement of "Canino" apricot. J. Agric. Res. Tanta Univ., 29 (1): 175 - 194.

Eissa-Fawzia, M. (2003b). Effect of some biostimulants on vegetative growth, yield and fruit quality of "Kelsey" plum. Egypt. J. of Appl. Sci. 18. (58).

El-Haddad, M. E.; Ishac, Y. Z. and Mostafa, M. L. (1993). The role of bio fertilizers in reducing agricultural costs, decreasing environmental pollution and raising crop yield. Arab Univ. J. of Agric. Sci., Ain Shams Univ. Cairo, 1 (1): $147-195$.

El-Naggar, Y. I. M. (2009). Physiological studies on fertilization of young apricot trees (Canino) cultivar.Ph.D.Thesis, Fac. of Agric. Banha Univ., Egypt.

El-Sehrawy, O. A. M. (2008). Influence of bio and organic fertilization on growth of Anna apple in the reclaimed 
land. Ph.D. Thesis Fac. of Agric., Shebin El-Kom, ElMenofiya Univ., Egypt.

El-Sayed, H. A. (2001). Relation between using yeast and nitrogen application in Flame vines. Annals of Agric. Sci., Moshtohor, 39 (4):2415 - 2427.

Faissal F. Ahmed; Hamdy I.M. Ibrahim and Mohamed Kh. Kamel. (2014).Date palm orchards by using humic acid and effective microorganisms. World Rural Observations; 6(2):102-110.

Fathi, M. A.; Eissa- Fawzia, M. and Yehia, M. M. (2002). Improving growth, yield and fruit quality of "Desert Red" peach and "Anna" apple by using some biostimulants. Minia J. Agric. Res. \& Develop., 22 (4): 519 - 534.

Gad-El-Kareem, M. R. (2009). Response of Swelling and Floridaprince peach trees to application of some restbreaking chemicals as well as organic and biofertilization under Sohag conditions. Ph.D.Thesis.Fac. of Agric. Minia Univ., Egypt.

Gaser-Aisha, S.A; El-Helw, Hanna, A. and Abd El- Wahab, M. A. (2006). Effect of yeast doses and time of application on growth, yield and fruit quality of Flame seedless grapevines.Egypt.J.Appl.Sci. 21 (8B): 661-681.

Hegab, M. M.; Fawzi, M. I. F. and Ashour, N. E. (2010). Effect of different yeast doses and time of application on growth, yield and quality of Ruby seedless grapevines. Minia J. of Agric. Res. \& Develop.30, 2:231 - 242.

Higa, T. and Wididana, G. N. (1991).Changes in the soil micro flora induced by effective microorganisms. In: J.F. Parr, S.B. Hornick, and C.E. Whitman (Ed.), Proc. of the $1^{\text {st }}$ Inter. Conf. on Kyusei Nature Farming. pp. 153-163. Dept. of Agric., Washington, D.C. USA.

Kabeel, H.; Abd El-Latif, F. M. and Abaza, M. S. M. (2008). Growth, fruiting and nutritional status of "Le-Conte" pear trees in response to mineral and humate fertilizers. Annals of Agric. Sci. Moshtohor, Vol. 46 (2): 139 - 156.

Kabeel, H.; Abd El-Latif, G. S. and Khalil, A. A. (2005).Effect of soil application of different mineral and bio-fertilizer treatments on growth, fruiting parameters, fruit properties and leaf nutrient content of "Canino" apricot trees. J. of Agric. Sci. Mansoura Univ. 30 (3): 1583 $-1594$.

Kabeel, H.; Abou Grah,F.I.;Hussein, Sh. M. and Abd ElMesseh, W. M. (2007). Influence of different levels of mineral fertilization and biofertilizers on vegetative growth, fruiting, fruit quality and nutritional status of "Anna" apple trees. Res. J. So. En. Se. Vol. (41), No. (11): pp. $54-79$.

Kannaiyan, S. (2002). Biotechnology of Biofertilizers. Alpha Sci. Inter. Ltd., P.O. Box 4067 Pangbourne R. 68 U.K., pp. 1-275.

Khattab, Magda M., A. E. Shaban, A. El-Shrief and A. Mohamed (2012). Effect of humic acid and amino acids on pomegranate trees under deficit irrigation. I: Growth, flowering and fruiting. Journal of Horticultural Science \& Ornamental Plants, 4: 253-259.
Lane, J. H. and Eynon, L. (1965). Determination of reducing sugars by means of Fehling's solution with methylene blue as indicator: A.O.A.C. Washington D.C., U.S.A. pp. $490-$ 510.

Li, N.; X. X. Wang and B. L. Lu. (1999). Study of the effect of apple liquid fertilizer on the growth and fruit development of apple Starkrimson apple variety. China fruits, 4: $20-21$ (c. a. Hort. Abst. 70, 5: 3628).

Mansour, A. E. M. (1998). Response of Anna apple to some bio fertilizers. Egyptian J. of Hort., 25(2): 241 - 251.

Mansour, A.E.M., Ahmed, F.F., Abdelaal, A.M.K., Eissa, R.A.R. and El-Sehrawy, O.A.M.(2013).The beneficial of using some biostimulants as a partial replacement of chemical $\mathrm{N}$ fertilizers in Floridaprince peach orchards. Journal of Applied Sciences Research, 9(1): 867-871.

Mansour, A. E. M.; Ahmed, F. F.; Ragab, A. M. and Danvish, O. H. (1998). Effect of some organic and amino acids on alleviating the adverse effects of salinity on El- Hamawy apricot seedlings. Egypt J. of Hort., 25(3): 359 - 369.

Mead, R.; Currow, R. N. and Harted, A. M. (1993). Statistical Methods in Agricultural Biology, $2^{\text {nd }}$ Ed. Chapman \& Hall, London, PP. 54 - 60.

Myint,C.C.(1999).EM Nature Farming Technology, Res. and Extension Activities in Myanmar. $6^{\text {th }}$ Inter.Conf.on Kyusei Nature Farming, Pretoria South Africa,28 -30.

Numair -Safaa, A. (2001). Effect of some $\mathrm{GA}_{3}$, vitamins and active dry yeast treatments on vegetative growth, yield and fruit quality of Thompson seedless grapevines. Zagazig Univ., Fac. of Agric., 1 (6): 634 - 644.

Patti, A.F., Levi-Minzi, R., Riffaldi, R., and Guidi, G. (1988). Liquid humic extracts and their uses in agriculture- An overview, in Proceedings: Science, technology, and utilization of humic acids, Conference held at CSIRO Division of Coal Technology (Australia), p. 96-105.

Petrovic, P; Vitrovic, D. and Jablanovic, M. (1982). Investigation of biological effects of humic acids. Acta Biol. Med. Exp., 7: $21-25$.

Russo, R. O. and G. P. Berlyn. (1990). The use of organic biostimulants to help low input sustainable agriculture. J. Sustainable Agric. 1 (2): 19 - 42.

Senn, T. L. and A. R. Kingman. (1973). A review of humus and humic acids. Res. Series No. 165. South Carolina Agricultural Experiment Station, ClemsonUniv.

Shaddad, G.; Khalil, A. and Fathi, M. A. (2005). Improving growth, yield and fruit quality of "Canino" apricot by using bio, mineral and humate fertilizers. Minufiya J. Agric. Res., 30 (1): 317-328.

Summer, M.E. (1985). Diagnosis and recommendation integrated system (DRIS) asa guide to orchard fertilization. Hort. Abst., 55(8): 7502.

Tatini, M.; P. Bertoni; A. Landi and M. L. Traversi. (1991). Effect of humic acids ongrowth and biomass portioning of container-grown olive plants. Acta Hort. 294: 75 - 80 .

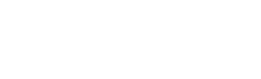




\title{
قلالل كمية النترات والنيتربت في ثمار الفاح الأنّا بلستخدالم النسميد الغيرعضوي مع الكائنت القيقة الفعالة والخميرة وحامض الهيوميك
}

\author{
لأسلمه علي محمد اللسحراوي
}

اللثمار، وكلت أفضل هذه المشططت الطبيعية الحيورية هـ:الكائنت الدقيقة الفعالة، أما حلمض الهنات الهيوميك فقد لحنل المركز الثاني في هذا الصدد. لأبل نقلبل النالوث النانج عن وجود النترات والنيتريت في الثار، وأيضا لتمسين إنتلجية لُشجار الفاح "الأنّا " فإنه

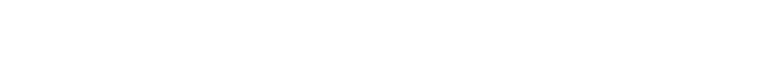

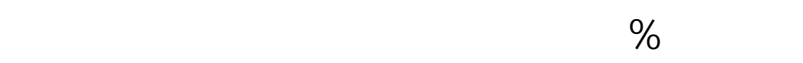

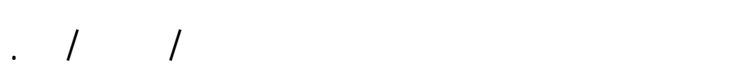

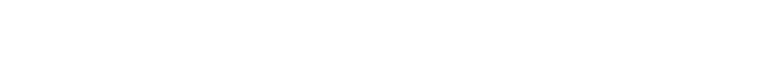
مواد منشطة طبيعية حيوية هـ: الكائنات الدقية الفعالة، الخميرة وحلمض الهيوميك كبديل جزئي للسماد النيتروجيني الفينة الغيرعضوي في بستن فاح صف "الأنَّا".

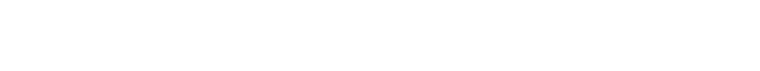
الغيرعضوي - جنبا إلى جنب مع أي من هذه المنشطلت

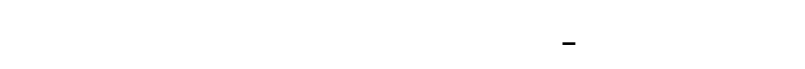

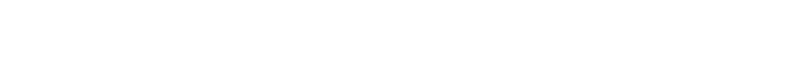
الغذائية للمأشجار، وكمية المحصول، وخصائص الجونة 